\title{
WIEDZA STUDENTÓW NA TEMAT MASTEKTOMII I WYBRANYCH METOD REKONSTRUKCJI PIERSI U PACJENTEK PO MASTEKTOMII
}

\section{KNOWLEDGE OF STUDENTS ABOUT MASTECTOMY AND SELECTED METHODS OF BREAST RECONSTRUCTION IN PATIENTS AFTER MASTECTOMY}

\author{
Anna Żeruń ${ }^{1, a}$, Tomasz Piątek ${ }^{2, b}$ \\ ${ }^{1}$ studentka, kierunek Pieleggniarstwo, Wydział Nauk o Zdrowiu, Warszawski Uniwersytet Medyczny \\ ${ }^{2}$ Zakład Pielęgniarstwa Chirurgicznego, Transplantacyjnego i Leczenia Pozaustrojowego Warszawskiego Uniwersytetu Medycznego \\ ${ }^{a}$ https://orcid.org/0000-0002-1862-7448 \\ ${ }^{\mathrm{b}} \mathrm{https} / / /$ orcid.org/0000-0001-5052-6690
}

DOI: https://doi.org/10.20883/pielpol.2020.25

\section{STRESZCZENIE}

Wstęp. Utrzymująca się w Polsce tendencja wzrostowa zachorowalności na raka piersi wpłynęła na rozwój onkoplastyki. Jest to szczególnie ważne dla pacjentek po radykalnej mastektomii. Metody rekonstrukcji piersi są permanentnie poprawiane i udoskonalane. W związku z tym obecna i przyszła kadra medyczna powinna posiadać wiedzę na temat zabiegów odtwórczych piersi.

Cel. Celem badania było poznanie poziomu wiedzy studentów kierunku pielęgniarstwo i położnictwo Warszawskiego Uniwersytetu Medycznego na temat mastektomii i wybranych metod rekonstrukcji piersi u pacjentek po mastektomii oraz porównanie wiedzy studentów obu tych kierunków.

Materiał i metody. Badaniami objęto dogodnościową grupę studentów kierunków pielęgniarstwo $(n=106)$ i położnictwo $(n=102)$ studiów I i ll stopnia Warszawskiego Uniwersytetu Medycznego. Do oceny poziomu wiedzy użyto autorskiego kwestionariusza ankiety.

Wyniki. Wiedza studentów kierunku pielęgniarstwo i położnictwo na temat wybranych metod rekonstrukcji piersi u pacjentek po mastektomii jest na takim samym poziomie. Niezależnie od wybranego kierunku studenci prezentują wyższy poziom wiedzy na temat mastektomii aniżeli na temat rekonstrukcji piersi.

Wnioski. Wiedza studentów obu kierunków z zakresu rekonstrukcji piersi jest na niskim poziomie. Istnieje potrzeba uzupełnienia przedmiotowej wiedzy na ten temat $w$ trakcie kształcenia przedi podyplomowego.

SŁOWA KLUCZOWE: pierś, mastektomia, mammoplastyka, studenci, wiedza.

\section{Wprowadzenie}

Zgodnie z danymi statystycznymi w Polsce z roku na rok wzrasta ilość osób dotkniętych rakiem piersi. Jest to najczęściej występujący nowotwór złośliwy u kobiet

\begin{abstract}
Introduction. The upward trend in the incidence of breast cancer in Poland has affected the development of oncoplastic surgery. This is especially important for patients after a radical mastectomy. Breast reconstruction methods are permanently corrected and improved. Therefore, current and future medical staff should have knowledge about breast restorative procedures.

Aim. The purpose of this study was to assess and compare the levels of knowledge of nursing and obstetrics students of the Medical University of Warsaw about mastectomy and selected methods of breast reconstruction after mastectomy.

Material and methods. The study included a convenience sample of nursing $(n=106)$ and obstetrics $(n=102)$ students of 1 st and 2nd-degree studies at the Medical University of Warsaw. The author's questionnaire was used to assess the level of knowledge. Results. The knowledge of nursing and midwifery students on selected methods of breast reconstruction in patients after a mastectomy is at the same level. Regardless of the chosen field of study, students present a higher level of knowledge about mastectomy than breast reconstruction.

Conclusions. The knowledge of students of both faculties about breast reconstruction is at a low level. There is a need to supplement a subject knowledge during the pre-diploma and postdiploma education.
\end{abstract}

KEYWORDS: breast, mastectomy, mammoplasty, students, knowledge.

(18 615 zachorowań w 2016 roku; 22,8\% ogółu zachorowań na nowotwory złośliwe) [1]. Wedle prognoz Zakładu Epidemiologii i Prewencji Nowotworów do 2025 roku liczba zachorowań zwiększy się. Będzie to w różnym 
stopniu dotyczyło przedstawicielek wszystkich grup wiekowych, nie tylko tych w okresie okołomenopauzalnym [2].

Leczenie zależne jest od stadium choroby. Powinno uwzględniać aspekty, takie jak typ histologiczny, stopień zaawansowania guza, złośliwość raka, obecność i lokalizacja przerzutów, przebyte i współistniejące choroby, jak również stan sprawności i preferencje chorej. Przy tworzeniu i wdrażaniu w życie indywidualnego planu opieki współpracować powinno wielu specjalistów. Wśród nich wyróżnić można przedstawicieli takich dziedzin, jak: radiologia, radioterapia onkologiczna, onkologia kliniczna, chirurgia onkologiczna, patologia, chirurgia plastyczna, rehabilitacja czy psychoonkologia [3]. Przed rozpoczęciem właściwej terapii pacjentka powinna zostać powiadomiona w sposób zrozumiały o wszystkich możliwych do wybrania w jej przypadku sposobach leczenia. Informacje te powinny obejmować nie tylko kwestie usunięcia guza, lecz także dostępne metody odtwórcze wraz z przejrzystym opisem wad i zalet z nimi związanych. Udział pacjentki w planowaniu leczenia powinien zwiększyć jej poczucie odpowiedzialności za własne zdrowie, poprawić współpracę z personelem medycznym, zmniejszyć poczucie strachu przed nieznanym oraz pomóc wyzbyć się nierealnych oczekiwań względem możliwych do osiągnięcia efektów estetycznych [4]. Do metod leczenia raka piersi zaliczane są zarówno zabiegi oszczędzające, jak i amputacja. Mimo przeważającej na świecie tendencji do stosowania terapii oszczędzającej, w Polsce z powodu opóźnionej wykrywalności nowotworu piersi wciąż wiele kobiet poddawanych jest mastektomii radykalnej [5]. Obok metod leczniczych rozwinęły się także zabiegi odtwórcze. W nowoczesnej medycynie rekonstrukcja piersi stanowi standard, z którego przy braku przeciwwskazań powinna mieć szansę skorzystać każda chora [3]. Takie integralne podejście do leczenia wraz z rozwojem onkoplastyki wpłynęło na samą technikę amputacji piersi, która zaczęła ewoluować w kierunku podskórnego usunięcia guza z równoczesnym bądź planowanym odtworzeniem wyniosłości piersi [6].

Biorąc pod uwagę czas przeprowadzenia rekonstrukcji względem wykonania mastektomii, wyróżnić można trzy tryby zabiegu: jednoczasowy, odroczony lub ich połączenie. Wybór sposobu zależy między innymi od wyniku badania histopatologicznego, planowanego adjuwantowego leczenia onkologicznego (przede wszystkim radioterapii) czy też przeciwwskazań ze strony pacjentki do przedłużonego znieczulenia ogólnego. Zważywszy na rodzaj wykorzystanych tkanek metody odtwórcze obejmują wykorzystanie tkanek własnych pacjentki (uszypułowane i wolne płaty skórno-mięśniowe) lub użycie wszczepów z tworzyw sztucznych (ekspander i proteza bądź ekspanderoproteza) [4, 5]. Stosowane są także techniki mieszane [7]. Efekt końcowy nie zawsze jest satysfakcjonujący. W związku z tym dla poprawy efektu estetycznego niejednokrotnie konieczne jest wykonanie dodatkowej operacji. Asymetrię piersi niweluje się podczas zabiegu onkoplastycznego w obrębie piersi kontralatelarnej. Celem takiego działania jest przede wszystkim poprawa jakości życia pacjentki, choć z usunięcia części miąższu piersi zdrowej wynika też inna korzyść - zmniejszenie ryzyka pojawienia się tam w przyszłości niezależnego, metachronicznego nowotworu [8].

Oprócz potrzeby przeprowadzenia symetryzacji piersi, z zabiegami rekonstrukcyjnymi wiążą się liczne powikłania. Ich liczba, jak i charakter w istotny sposób związane są z wybraną metodą odtworzenia piersi. Znaczący wpływ mają tu również czynniki, takie jak: wiek pacjentki, otyłość, zaburzenia w tkance skórnej, palenie papierosów, choroby współistniejące (w tym: cukrzyca, miażdżyca, wrodzone i nabyte zespoły upośledzenia odporności, przewlekła niewydolność nerek), przebyte zabiegi w obrębie jamy brzusznej, chemio- i radioterapia, przewlekłe stosowanie leków sterydowych, jak również doświadczenie chirurga [7, 9].

Współcześnie w kulturze istnieje pewien kanon piękna odnoszący się między innymi do wyglądu kobiecego ciała. Pierś uznawana jest za symbol atrakcyjności oraz macierzyństwa. Z uwagi na to jakiekolwiek zmiany w jej wyglądzie skutkują obniżeniem samooceny i poczuciem wstydu. Badacze określają ten syndrom jako „kompleks połowy kobiet". Warto podkreślić, iż negatywne konsekwencje zabiegów oszczędzających, jak i amputacji odnoszą się nie tylko do intymnej sfery życia, lecz wpływają na całościowe postrzeganie swojej osoby i wywołują trudności psychospołeczne [10, 11]. W związku z powyższym onkoplastyka odgrywa bardzo ważną rolę w nowoczesnym podejściu do leczenia. Badania wskazują, iż rekonstrukcja piersi wywołuje korzystny wpływ na stan psychologiczny chorych [12]. Chociaż zaobserwować można systematyczny wzrost liczy kobiet korzystających z możliwości leczenia onkoplastycznego, wciąż znaczna część chorych nie decyduje się na zabieg odtworzenia piersi. W Polsce, mimo refundacji finansowych ze strony Narodowego Funduszu Zdrowia, tylko około $6 \%$ kobiet decyduje się na skorzystanie z możliwości rekonstrukcji [12, 13].

W związku z prognozowanym w najbliższych latach wzrostem zachorowań na raka piersi, a także nieustannym rozwojem onkoplastyki istnieje potrzeba przeprowadzenia badania wiedzy studentów kierunku pielęgniarstwo i położnictwo - przyszłych pracowników ochrony zdrowia - na temat mastektomii i wybranych metod rekonstrukcji piersi. Otrzymane wyniki mogą być 
przydatne dla dyrekcji szpitali onkologicznych, jak również dla osób odpowiedzialnych za tworzenie programów kształcenia przeddyplomowego i podyplomowego dla pielęgniarek i polożnych.

\section{Cel pracy}

Celem badania było poznanie poziomu wiedzy studentów kierunków pielęgniarstwo i położnictwo Warszawskiego Uniwersytetu Medycznego na temat wybranych metod rekonstrukcji piersi u pacjentek po mastektomii oraz porównanie poziomu wiedzy studentów obu tych kierunków.

Tworząc kwestionariusz ankiety, skupiono się na uzyskaniu odpowiedzi na kilka zagadnień: „Czym jest mastektomia i kogo może dotyczyć ten zabieg?”, „Na czym polega rekonstrukcja piersi?, a także „Jakie są sposoby odtworzenia wyniosłości piersi oraz kto może poddać się temu zabiegowi?".

\section{Materiał i metody}

Badanie przeprowadzono w okresie od kwietnia do października 2019 roku na dogodnościowej grupie studentów kierunków pielęgniarstwo i położnictwo Warszawskiego Uniwersytetu Medycznego. Udział w badaniu był dobrowolny, a respondenci zostali powiadomieni o anonimowości ankiety. Ostateczną grupę stanowiło 208 osób, w tym 106 studentów pielęgniarstwa i 102 studentów położnictwa. Charakterystyka badanej grupy została przedstawiona w tabeli 1.

W badaniu wykorzystano kwestionariusz ankiety własnego autorstwa. Skupiono się na uzyskaniu odpowiedzi na kilka zagadnień: „Czym jest mastektomia i kogo może dotyczyć ten zabieg?”, „Na czym polega rekonstrukcja piersi?, a także „Jakie są sposoby odtworzenia wyniosłości piersi oraz kto może poddać się temu zabiegowi?".

Kwestionariusz składał się z kilku części. Pierwsza z nich informowała o celowości przeprowadzenia badania. W kolejnej części znajdowały się 22 pytania zamknięte: 6 dotyczących mastektomii oraz 16 dotyczących rekonstrukcji piersi. Pytania dotyczące mastektomii koncentrowały się na definicji i rodzajach zabiegu. $\mathrm{Na}$ część o metodach odtwórczych składały się między innymi pytania o to, czym jest rekonstrukcja, jakie rodzaje zabiegu wyróżniamy, jakie są wskazania oraz przeciwwskazania do jego przeprowadzenia, a także możliwe powikłania po zabiegu. Kilka punktów ankiety dotyczyło również zagadnień, takich jak ekspander, implant oraz wolne i uszypułowane płaty skórno-mięśniowe. Poniżej przedstawiono kolejne pytania:
1) Co to jest mastektomia? 2) Kto może zostać poddany mastektomii? 3) Jakie rodzaje mastektomii wyróżniamy? 4) Czy mastektomia może zostać przeprowadzona jako zabieg profilaktyczny? 5) Pacjentka poddana została prawostronnej mastektomii. W jakiej pozycji po przebytym zabiegu powinna być ułożona ręka pacjentki po stronie operowanej? 6) Co ma na celu właściwe ułożenie kończyny górnej po stronie operowanej u pacjentki po przebytej mastektomii? 7) Co to jest rekonstrukcja piersi? 8) Jakie rodzaje rekonstrukcji piersi wyróżniamy? 9) Jakie metody rekonstrukcji piersi wyróżniamy? 10) Czy możliwe jest przeprowadzenie rekonstrukcji piersi u pacjentki, która zastała poddana mastektomii 15 lat wcześniej? 11) Zaznacz wskazania do rekonstrukcji piersi (pytanie wielokrotnego wyboru). 12) Zaznacz przeciwwskazania do rekonstrukcji piersi (pytanie wielokrotnego wyboru). 13) Zaznacz możliwe powikłania po zabiegu rekonstrukcji piersi (pytanie wielokrotnego wyboru). 14) Co to jest przykurcz torebkowy? 15) Jaki rodzaj znieczulenia stosowany jest do przeprowadzenia zabiegu rekonstrukcji piersi? 16) Co to jest ekspander? 17) Czym wypełnia się ekspander? 18) Po jakim czasie należy wymienić implant użyty do rekonstrukcji piersi? 19) Co to jest płat TRAM (ang. transverse rectus abdominis myocutaneous flap)? 20) Co to jest płat LD (łac. latissimus dorsi)? 21) Co to jest płat uszypułowany? 22) Co to jest symetryzacja piersi?

Nie obliczano dla każdego badanego punktacji całkowitej za całość testu. Przyjęto trzy kategorie poziomu wiedzy studentów: poziom niski (0-50\% poprawnych odpowiedzi), poziom umiarkowany $(<50-75 \%)$, poziom wysoki (< 75-100\%). Porównano poziom wiedzy badanych na temat mastektomii, jak i rekonstrukcji piersi.

Na końcu kwestionariusza umieszczona była metryczka umożliwiająca zebranie danych socjodemograficznych. Zawierała ona pytania o takie kwestie, jak: płeć, wiek, kierunek, stopień i rok studiów, ukończone wcześniej studia medyczne, miejsce pracy, staż pracy w zawodzie.

Badania zostały przeprowadzone za zgodą Komisji Bioetycznej przy Warszawskim Uniwersytecie Medycznym nr AKBE/146/2019.

\section{Analizy statystyczne}

Różnice między grupami niepowiązanymi badano testem nieparametrycznym $U$ Manna Whitneya, a zależności między zmiennymi powiązanymi za pomocą testu $Z$ Wilcoxona. Przyjęto poziom $p=0,05$ jako próg istotności statystycznej. Analizy zebranych danych dokonano w programie SPSS wersja 21. 
Tabela 1. Charakterystyka grupy badanej

Tabele 1. Characteristic of the study group

\begin{tabular}{|c|c|c|c|}
\hline $\begin{array}{l}\text { Cecha/ } \\
\text { Feature }\end{array}$ & $\begin{array}{l}\text { Charakterystyka/ } \\
\text { Characteristics }\end{array}$ & $\begin{array}{l}\text { Liczba respondentów/ } \\
\text { Number of respondents }\end{array}$ & $\%$ \\
\hline \multirow{2}{*}{ Płeć/Sex } & Kobieta/Woman & 205 & 98,6 \\
\hline & Mężczyzna/Man & 3 & 1,4 \\
\hline \multirow{4}{*}{ Wiek/Age } & $18-19$ & 46 & 22,1 \\
\hline & $20-21$ & 73 & 35,1 \\
\hline & $22-23$ & 69 & 33,2 \\
\hline & 24 i więcej/24 and more & 20 & 9,6 \\
\hline \multirow{2}{*}{ Kierunek studiów/Field of study } & Pielęgniarstwo/Nursing & 106 & 51 \\
\hline & Położnictwo/Midwifery & 102 & 49 \\
\hline \multirow{3}{*}{$\begin{array}{l}\text { Stopień i tryb studiów/Degree of study } \\
\text { and study mode }\end{array}$} & $1^{\circ}$ & 146 & 70,2 \\
\hline & $\|^{\circ}$ (stacjonarne)/(full-time) & 59 & 28,4 \\
\hline & $\|^{\circ}$ (niestacjonarne)/(extramural) & 3 & 1,4 \\
\hline \multirow{5}{*}{ Rok studiów/Year of study } & Pierwszy/First & 87 & 41,8 \\
\hline & Drugi/Second & 35 & 16,8 \\
\hline & Trzeci/Third & 23 & 11,1 \\
\hline & Pierwszy mgr/First of Master's degree & 51 & 24,5 \\
\hline & Drugi mgr/Second of Master's degree & 12 & 5,8 \\
\hline \multirow{2}{*}{ Praca w zawodzie/Work in the profession } & Tak/Yes & 36 & 17,3 \\
\hline & Nie/No & 172 & 82,7 \\
\hline \multirow{2}{*}{$\begin{array}{l}\text { Staż pracy w zawodzie/Seniority in the } \\
\text { profession }\end{array}$} & $0-5$ lat $/ 0-5$ years & 35 & 16,8 \\
\hline & 6 lat i więcej/6 years and more & 1 & 0,5 \\
\hline
\end{tabular}

Źródło: opracowanie własne

Source: author's own analysis

\section{Wyniki}

Poziom wiedzy studentów pielęgniarstwa z zakresu mastektomii oceniono jako umiarkowany $(71,07 \%)$, a z zakresu rekonstrukcji piersi jako niski (40,42\%). Podobny poziom wiedzy prezentowali studenci położnictwa - umiarkowany z zakresu mastektomii $(67,65 \%)$ i niski z zakresu rekonstrukcji piersi (41,55\%). Wyniki dotyczące rozkładów odpowiedzi na poszczególne pytania przedstawiają ryciny 1 i 2.

W analizie danych wzięto pod uwagę zależność pomiędzy przeciętnym poziomem wiedzy (uzyskanej punktacji) a poziomem studiów. Wykazano istotne różnice pomiędzy studentami studiów magisterskich i licencjackich $(U=3517 ; p=0,04)$.

Badani na studiach magisterskich wykazywali wyższy poziom wiedzy o mastektomii (średnia ranga równa 116,39) niż badani na studiach licencjackich (średnia ranga 97,59). Sprawdzono także, czy kwestia aktywności zawodowej ma związek z poziomem ich wiedzy, jednak tu zależności nie stwierdzono $(U=2695,5 ; p=0,22)$.

Porównano również poziom wiedzy studentów o mastektomii względem poziomu wiedzy o wybranych metodach rekonstrukcji piersi. Poziom wiedzy o mastektomii był wyższy (średnia ranga równa 111,74) niż poziom wiedzy o metodach rekonstrukcji piersi (średnia ranga 40,05) $(Z=-11,54 ; p<0,001)$.

Przeanalizowano tę zależność także w podgrupach wyznaczonych przez kierunek studiów. Pośród badanych z kierunku pielęgniarstwo wiedza o mastektomii była wyższa niż wiedza o metodach rekonstrukcji
( $Z=-8,46 ; p<0,001$; średnia ranga wiedzy o mastektomii 58,08; o rekonstrukcji piersi 13,91). Podobne zróżnicowanie odnotowano wśród studiujących położnictwo ( $Z=-7,79 ; p<0,001$; średnia ranga wiedzy o mastektomii 53,91; o rekonstrukcji piersi 29,3).

W badaniu nie wykazano natomiast istotnej różnicy poziomu wiedzy na temat rekonstrukcji piersi po mastektomii pomiędzy studentami pielęgniarstwa i położnictwa $(p=0,8)$. Analizy pokazały ponadto, iż żadna z grup nie wyróżniała się pod względem znajomości wskazań $(U=4688,5$; $p=0,085)$ i przeciwwskazań $(U=5234 ; p=0,69)$ do przeprowadzenia zabiegu odtwórczego.

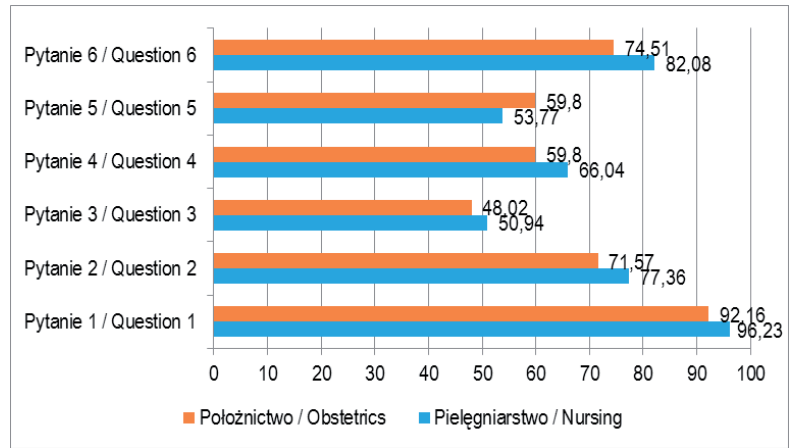

Rycina 1. Poprawność odpowiedzi studentów na pytania dotyczące mastektomii

Figure 1. The correctness of students' answers to questions about mastectomy

Źródło: opracowanie własne

Source: author's own analysis 


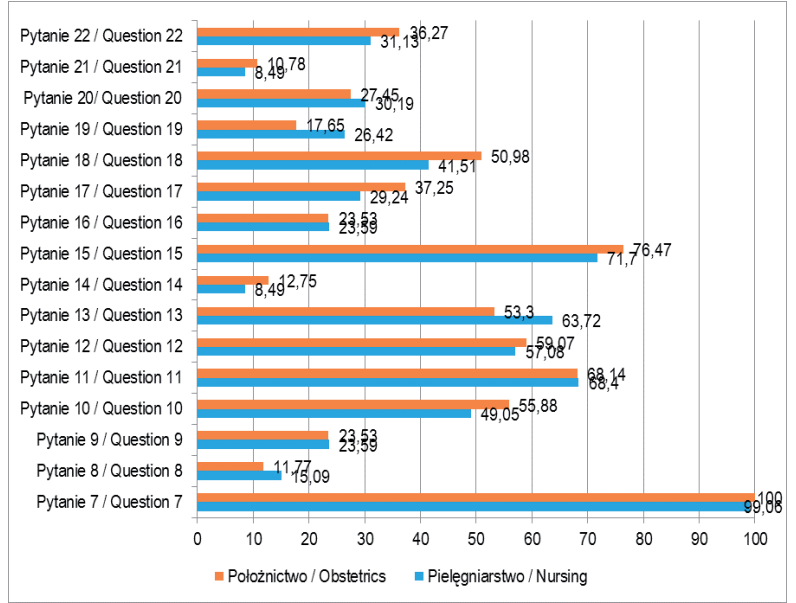

Rycina 2. Poprawność odpowiedzi studentów na pytania dotyczące rekonstrukcji piersi

Figure 1. The correctness of students' answers to questions about breast reconstruction

Źródło: opracowanie własne

Source: author's own analysis

\section{Dyskusja}

W literaturze polskiej i światowej są publikacje prezentujące wiedzę pacjentów na temat rekonstrukcji piersi, zakresu pomocy udzielanej pacjentkom po przebytej mastektomii przez personel pielęgniarski, motywów wpływających na decyzję poddania się bądź rezygnacji z operacji, jak również oceny jakości życia kobiet w zależności od zastosowanego leczenia [11, 13, 15]. Nie ma natomiast prac badających poziom wiedzy studentów studiów medycznych na temat mastektomii i wybranych metod rekonstrukcji piersi po mastektomii. Biorąc pod uwagę potrzebę takich badań podjęto się niniejszego badania właśnie w populacji studentów pielęgniarstwa i położnictwa.

W badaniu wykazano istotne różnice pomiędzy poziomem wiedzy studentów studiów magisterskich i licencjackich. Ci pierwsi wykazali się wyższym poziomem wiedzy na temat mastektomii w porównaniu ze studentami studiów licencjackich.

Wyniki ankiety pokazały także, iż zarówno studenci pielęgniarstwa, jak i położnictwa prezentują wyższy poziom wiedzy na temat mastektomii w porównaniu z wiadomościami z zakresu rekonstrukcji piersi. Poziom wiedzy studentów obu kierunków z zakresu mastektomii oceniono jako umiarkowany (pielęgniarstwo - 71,07\%, położnictwo $-67,65 \%$ ), natomiast z zakresu rekonstrukcji piersi jako niski (pielęgniarstwo - 40,42\%, położnictwo - 41,55\%). Mastektomia to zabieg bardziej ogólny i znany, częściej poruszany w toku studiów, między innymi podczas zajęć z chirurgii czy onkologii. Uzyskane przez studentów wyniki świadczą o dość dobrej znajomości tego zagadnienia. Z kolei onkoplastyka to dziedzina specyficzna, którą bliżej poznać można raczej podczas szkolenia specjalizacyjnego aniżeli $w$ trakcie studiów I i ll stopnia. Nie dziwi więc fakt, iż poziom wiedzy studentów na ten temat jest niższy.

Dla pacjentek okres otrzymania diagnozy, przebycia operacji amputacji piersi oraz poddania się jednoczasowej bądź odroczonej rekonstrukcji wiąże się z dużym stresem. Autorzy różnych badań wskazują na szczególne potrzeby chorych w tym trudnym czasie. Pacjentki wymagają pomocy nie tylko ze strony stricte medycznej, lecz także, a może przede wszystkim, wsparcia psychicznego. Kluczową rolę w zapewnieniu odpowiedniej opieki pełnią pielęgniarki i położne. Mając częsty i bezpośredni kontakt z pacjentką, mogą reagować na ich stany emocjonalne, umożliwić kontakt z rodziną i bliskimi, jak również zapewnić dostęp do grup wsparcia. Stanowią też cenne źródło informacji co do przebiegu leczenia i rekonwalescencji. Analizy wcześniejszych badań wskazują, iż pacjentki, które są lepiej poinformowane w zakresie swojej choroby oraz mają świadomość możliwości kontaktu z pracownikiem ochrony zdrowia, czują się spokojniejsze i lepiej przechodzą proces rekonwalescencji [16]. Wynika z tego, iż lepsze zrozumienie potrzeb pacjentek, które przebyły operację odtwórczą piersi, może pomóc w całościowej poprawie opieki zapewnionej chorej.

Badania dowodzą, iż poddanie się operacji odtwórczej piersi przyczynia się do poprawy stanu psychicznego chorych i akceptacji wyglądu swojego ciała [12]. Wiele kobiet jednak odczuwa niezadowolenie z przebytego zabiegu. Główną przyczyną jest nieodpowiednie przygotowanie chorej do zabiegu przez personel medyczny. Brak wiadomości w zakresie całościowej opieki, możliwych powikłań, użyteczności masażu, wielkości blizn i możliwości nawrotu choroby jest dla pacjentek niezwykle stresujący i skutkuje powstawaniem nieadekwatnych oczekiwań co do zabiegu i przewidywanych efektów. Pacjentki są zaskoczone długim czasem rekonwalescencji, towarzyszącymi dolegliwościami bólowymi, ograniczeniem ruchomości odtworzonej piersi, brakiem naturalności i poczuciem sztuczności w dotyku, jak również dużą ilością blizn [17].

Aby zminimalizować liczbę chorych niezadowolonych z efektów przebytej operacji, ważne jest zapewnienie pacjentkom dostępu do rzetelnych źródeł informacji na temat metod odtwórczych. Badania wskazują, iż poziom wiedzy posiadanej przez pacjentkę jest jednym z czynników odgrywających ważną rolę w procesie podejmowania decyzji o poddaniu się operacji odtwórczej piersi [18]. Z uwagi na różnorodność i specyfikę rekonstrukcji piersi personel medyczny powinien posiadać odpowiedni zasób wiedzy, aby właściwie przedstawić zarówno możliwości, jak i zagrożenia płynące $z$ tego 
typu zabiegu. Co więcej, odpowiednie przygotowanie pacjentki i personelu zapewni efektywną współpracę w okresie przed- i pooperacyjnym oraz pozwoli uniknąć niektórych powikłań.

Znacząca grupa respondentów w niniejszym badaniu $(82,7 \%)$ to osoby, które nie podjęły jeszcze pracy w zawodzie. Mają zatem jeszcze czas, aby niedostatek wiedzy uzupełnić w trakcie studiów. Wyniki niniejszego badania mogą być użyteczne dla kadry dydaktycznej kierunków pielęgniarstwo i położnictwo w doborze treści kształcenia w ramach programów studiów. Mogą być też przydatne dla autorów programów kształcenia podyplomowego.

\section{Wnioski}

1. Poziom wiedzy studentów kierunków pielęgniarstwo i położnictwo Warszawskiego Uniwersytetu Medycznego z zakresu mastektomii jest umiarkowany.

2. Poziom wiedzy studentów kierunków pielęgniarstwo i położnictwo Warszawskiego Uniwersytetu Medycznego z zakresu rekonstrukcji piersi jest niski.

3. Należałoby rozważyć szersze uwzględnienie zagadnień z zakresu rekonstrukcji piersi w programach kształcenia na studiach I i Il stopnia.

\section{Piśmiennictwo}

1. Wojciechowska U, Czaderny K, Ciuba A, Olasek P, Didkowaska J. Nowotwory złośliwe w Polsce w 2016 roku. Krajowy Rejestr Nowotworów, Zakład Epidemiologii i Prewencji Nowotworów, Centrum Onkologii Instytut im. Marii Skłowodskiej-Curie, Narodowy Program Zwalczania Chorób Nowotworowych. Warszawa 2018; 33-64.

2. Didkowaska J, Wojciechowska U. Nowotwory piersi w Polsce i Europie - populacyjny punkt widzenia. Nowotwory. Journal of Oncology 2013; 63(2): 111-118.

3. Jassem J, Krzakowski M, Bobek-Billewicz B, Duchnowska R, Jeziorski A, Olszewski W, Senkus-Konefka E, Tchórzewska-Korba H, Wysocki P. Breast cancer. Oncol Pract Clin. 2018; 14: 225-250.

4. Jankau J, Skokowski J, Renkielska A. Znaczenie czasu rekonstrukcji piersi po mastektomii. Forum Med. Rodz. 2011; 5(3): 210-216.

5. Rykała J, Zieliński T, Kruk-Jeromin J. Odroczona, dwuetapowa rekonstrukcja piersi z użyciem wszczepów. Leczenie Ran 2010; 7(1-2): 5-12.

6. Bocian A, Kurzych K, Budner M, Kędzierawski P, Maliszewski D, Jasnowski P. Onkolplastyka - nowa filozofia chirurgicznego leczenia raka piersi. Chirurgia Plastyczna i Oparzenia 2015; 3(3): 129-139.
7. Jankau J, Renkielska A. Powikłania związane z zabiegiem rekonstrukcji piersi. Forum Med. Rodz. 2011; 5(3): 302-309.

8. Tarkowski R, Hap A, Bojarowski T. Rak gruczołu piersiowego znaleziony przypadkowo podczas symetryzacji piersi towarzyszącej rekonstrukcji. www.przypadkimedyczne.pl, 12.10.2019r. 15: 20.

9. Pałubicka A, Wekwejt M, Świeczko-Żurek B, Zieliński J. Powikłania po rekonstrukcji piersi: problem zakażeń i strategii prewencyjnej - przegląd literatury. Chirurgia Plastyczna i Oparzenia 2017; 5(3): 89-97.

10. Salmeri-Brandt A, Przybyła-Basista H. Obraz ciała a samoocena kobiet $z$ rakiem piersi - rola akceptacji ciała. Psychoonkologia 2018; 22(1): 1-10.

11. Brandt A, Przybyła-Basista H. Decyzja o rekonstrukcji piersi u kobiet po mastektomii - motywy, objawy, percepcja efektów. Psychoonkologia 2016; 20(1): 17-26.

12. Kozakiewicz B, Chądzyńska M. Operacje odtwórcze piersi powód lęku i rezygnacji. Acta Scholae Superioris Medicinae Legnicensis 2019; 2(22): 58-65.

13. Mazurek E. Amazońskie dylematy. Powody rezygnacji kobiet po chirurgicznym leczeniu raka piersi z zabiegu rekonstrukcji piersi. Psychoonkologia 2014; 3: 97-105.

14. Rozporządzenie Ministra Nauki i Szkolnictwa Wyższego z dnia 21 sierpnia 2019r. w sprawie standardów kształcenia przygotowującego do wykonywania zawodu lekarza, lekarza dentysty, farmaceuty, pielęgniarki, położnej, diagnosty laboratoryjnego, fizjoterapeuty i ratownika medycznego (Dz. U. 2019 poz. 1573).

15. Jankau J, Trus-Urbańska M, Renkielska A. Zmiana jakości życia po zabiegu rekonstrukcji piersi. Forum Med. Rodz. 2011, 5(5): 414-419.

16. Carr T, Groot G, Cochran D, Vancoughnett M, Holtslander L. Exploring women's Support Needs After Breast Reconstruction Surgery. Cancer Nurs. 2019, 42(2): E1-E9.

17. Carr T, Groot G, Cochran D, Holtslander L. Patient Information Needs and Breast Reconstruction After Mastectomy. Cancer Nurs. 2019, 42(3): 229-241.

18. Mazurek E. Znaczenie wiedzy w podejmowaniu decyzji o poddaniu się zabiegowi rekonstrukcji piersi przez kobiety leczone z powodu raka piersi. Onkol. Pol. 2012; 15(4): 166-170.

Artykuł przyjęty do redakcji: 12.05.2020.

Artykuł przyjęty do publikacji: 07.07.2020.

Źródło finansowania: Praca nie jest finansowana z żadnego źródła. Konflikt interesów: Autorzy deklarują brak konfliktu interesów.

Adres do korespondencji:

Anna Żeruń

ul. Żwirki i Wigury 61

02-091 Warszawa

tel: (0-22) 5720599

e-mail: anna.zerun@gmail.com

Wydział Nauk o Zdrowiu, Warszawski Uniwersytet Medyczny 